\title{
SORPTION OF COPPER(II) FROM AQUEOUS SOLUTION BY PEAT
}

\author{
Y. S. HO and G. MCKAY* \\ Department of Chemical Engineering, Hong Kong University of Science and Technology, \\ Clear Water Bay, Kowloon, Hong Kong \\ (*author for correspondence, e-mail: kemckayg@ust.hk)
}

(Received 21 February 2003; accepted 5 April 2004)

\begin{abstract}
The use of peat for removal of copper(II) from aqueous solution has been investigated at various initial copper ion concentrations and masses of peat. The equilibrium sorption study can be described by the Langmuir equation and defined in terms of the operating lines for each batch contacting system. The mechanisms of the rate of sorption of copper(II) were analysed using the Elovich equation and a pseudo-second-order model. Both rate mechanisms provided a very high degree of correlation of the experimental sorption rate data suggesting either model could be used in design applications.
\end{abstract}

Keywords: copper, kinetics, peat, sorption

\section{Introduction}

Since copper is an essential metal in a number of enzymes for all forms of life, problems arise when it is deficient or in excess. However, the carcinogenic character of copper is accepted and epidemiological evidence, such as the higher incidence of cancer among coppersmiths, suggests a primary carcinogenic role for copper (Luckey and Venugopal, 1977). In addition, copper is phytotoxic and, indeed, has been used as an algicide to control algal blooms. It can, therefore, cause plant damage if, for example, it is present at too high a concentration in sewage sludge that is applied to agricultural land. There are many routes by which metals can enter the air, water and soil as a result of man's activities. A principal source of copper in industrial waste streams is metal cleaning and plating baths, and rinses, as brass, boiler pipe, cooking utensils, fertilizers, and from copper metal working, which requires periodic oxide removal by immersing the metal in strong acid baths. Solution adhering to the cleaned metal surface is rinsed from the metal and contaminates the waste rinse water. Similarly, plated metal parts are also rinsed and produce wastewater.

For humans, copper is an essential element and the body can regulate its level haemostatically, although large, acute doses can have harmful, even fatal, effects. There is evidence to suggest that copper may be carcinogenic. In addition, copper can cause damage to a variety of aquatic fauna (fish and invertebrates).

During the past 20 years, most research work on peat has been focused on metal and organic removal from industrial waste streams. Indeed, even earlier,

Water, Air, and Soil Pollution 158: 77-97, 2004.

(c) 2004 Kluwer Academic Publishers. Printed in the Netherlands. 
Ong and Swanson (1966) reported on the ability of peat to adsorb copper from solution. Still earlier, Coleman et al. (1956) reported formation constants for $\mathrm{Cu}$ (II)-peat complexes. Many types of peat and potential processes to remove copper ions have been proposed (Ho et al., 1994). The sorption capacity of peat varies with the type of material being sorbed but because of its relatively low cost compared to other sorbents, it is believed that it will be able to compete successfully for particular applications (McKay et al., 1978). However, the search for new commercial uses of peat has been gaining extensive attention in the area of pollution control. Several biosorbents have been used as materials to adsorb copper from wastes including coconut coir husk (Low et al., 1995a,b), coir pith carbon (Namasivayam and Kadirvelu, 1997), agriculrural byproducts (Marshall et al., 1993) and chitosan (Findon et al., 1993; Ngah et al., 2002). Equilibrium studies on the use of peat to remove cadmium, copper, chromium, lead, mercury, nickel and zinc from a wide range of metal bearing wastewaters (Gosset et al., 1986; Viraraghavan and Dronamraju, 1993; Allen et al., 1992; Sharma and Forster, 1993; Ho et al., 1995; Ho and McKay, 2000; Ho et al., 2002).

In the present study the sorption of copper ions onto peat has been studied and a kinetic analysis has been developed and presented to establish the kinetic mechanism. The Elovich equation and pseudo-second-order equation have been compared and used to predict sorption rates.

\section{Materials and Methods}

The experiments were conducted with peat obtained from New Zealand. The peat as supplied, was dried at a temperature of $105 \pm 5^{\circ} \mathrm{C}$ for $8 \mathrm{~h}$ and then screened using sieves to obtain a particle size $500-710 \mu \mathrm{m}$ peat.

The copper sulphate used in the experiments was supplied by Aldrich Chemicals. Stock solutions of copper(II) sulphate (analytical grade $\left.\mathrm{CuSO}_{4} \cdot 5 \mathrm{H}_{2} \mathrm{O}\right)\left(1 \mathrm{~g} / \mathrm{dm}^{3}\right)$ were prepared in distilled water. All solutions used in this study were diluted with distilled water as required.

The $\mathrm{pH}$ of the initial solutions were buffered to 5.0 using sulphuric acid in order not to change the anion species. The effect of $\mathrm{pH}$ was not studied in the present work because peat is a natural buffer and the $\mathrm{pH}$ of all final solutions was $4.2 \pm 0.2$ $\mathrm{pH}$ units.

Equilibrium isotherms were determined by shaking a fixed mass of peat $(0.5 \mathrm{~g})$ with $125 \mathrm{~mL}$ copper(II) solution in screw cap plastic battle. A range of copper(II) concentrations were used. Shaking was carried out until equilibrium had been achieved. All contact investigations were carried out using a baffled agitated $2 \mathrm{dm}^{3}$ sorber vessel (Figure 1). Samples were withdrawn at suitable time intervals, filtered through a $0.45 \mu \mathrm{m}$ membrane filter and then analysed with an inductively coupled plasma atomic emission spectroscopy (ICP-AES). 


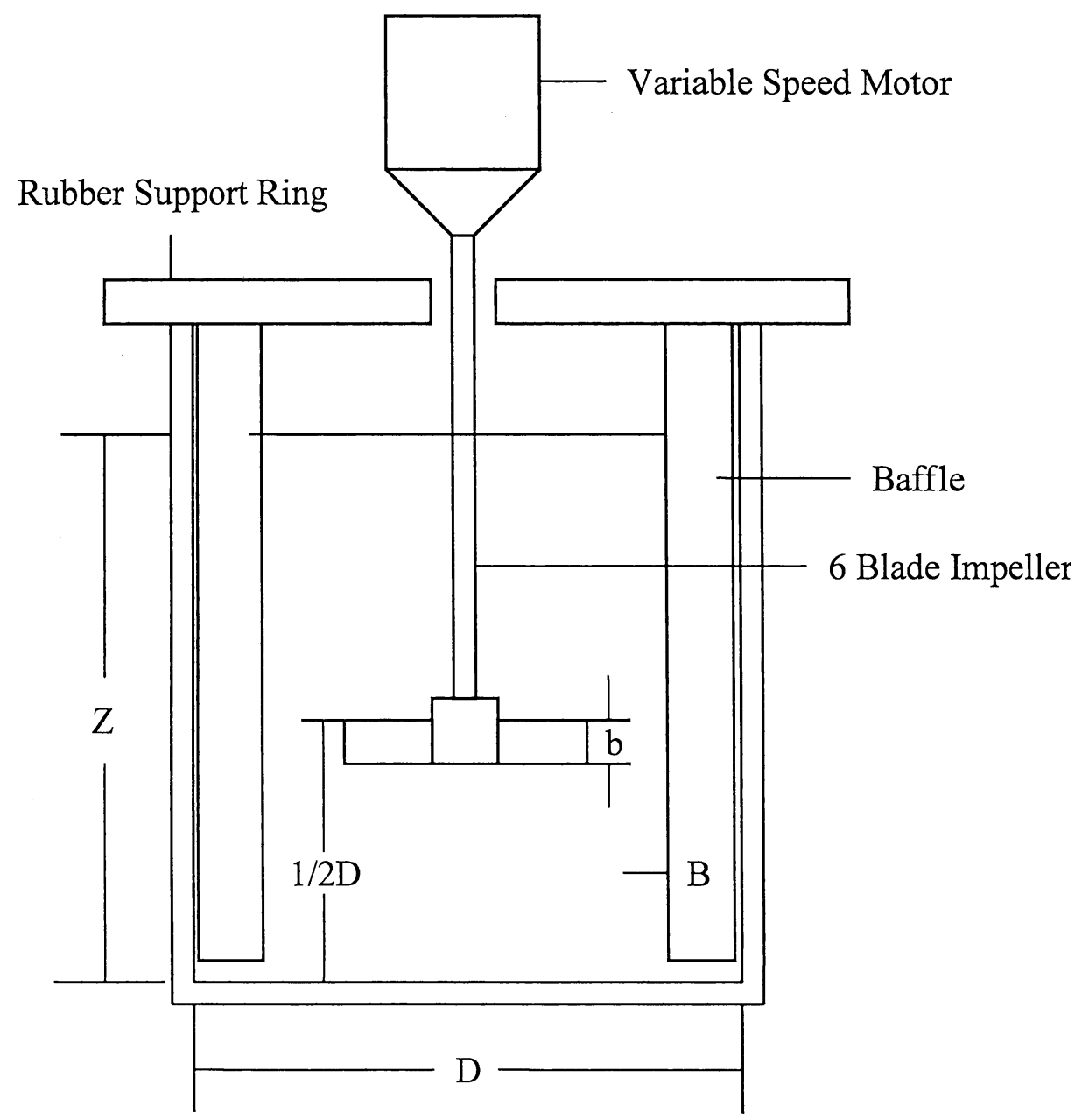

Figure 1. Schematic representation of sorber vessel.

The vessel contained $1.7 \mathrm{dm}^{3}$ copper(II) solution and was designed to conform to specified standards (Furusawa and Smith, 1973, 1974) for agitated mixing vessels.

\subsection{SORPTION DYNAMICS}

\subsubsection{Effect of Initial Concentration}

A $6.8 \mathrm{~g}$ sample of peat $(500-710 \mu \mathrm{m})$ was added to each $1.7 \mathrm{dm}^{3}$ volume of copper(II) solution. The initial concentrations of copper(II) solution tested were $0.643,1.33,1.56$ and $1.83 \mathrm{mmol} / \mathrm{dm}^{3}$. 


\subsubsection{Effect of Different Peat Masses}

$1.7 \mathrm{dm}^{3}$ volume of copper(II) solution $\left(1.33 \mathrm{mmol} / \mathrm{dm}^{3}\right)$ was used with masses of peat $(500-710 \mu \mathrm{m})$ to be tested, namely, 3, 4, 5 and $6 \mathrm{~g} / \mathrm{dm}^{3}$.

\subsection{EQUILIBRIUM ISOTHERMS}

Isotherm experiments were carried out at room temperature $\left(20 \pm 2{ }^{\circ} \mathrm{C}\right)$. The sorption isotherm was obtained by shaking various weights of the peat with particle size 500-710 $\mu \mathrm{m}$ with $125 \mathrm{dm}^{3}$ of copper(II) solution of known initial concentration in individual plastic bottles. The time to reach equilibrium was $3 \mathrm{~h}$, and after this time the solution was filtered and analysed for concentrations.

\section{Results and Discussion}

Several steps can be used to express the mechanism of solute sorption onto a sorbent. To investigate the mechanism of copper sorption and the potential rate controlling steps, such as diffusion mass transport and chemical reaction processes, it is necessary to characterize the main sorption mechanisms. Diffusion processes can be controlled by film/external boundary layer diffusion, diffusion in the liquidfilled pores of adsorbents or surface diffusion of sorbed-soluble molecules that migrate along the surface of the adsorbent. The rate controlling mechanism may be one diffusional mass transfer resistance or a combination of two or three of these processes. However, peat is composed of several thousand different chemical species that could be involved in a wide range of mechanisms such as physical adsorption, ion exchange with several organic acids, chelation, lone pair electron sharing, chemical reaction with phenolic hydroxyls or other similar species. Due to this wide range of possible copper removal processes on peat we have used the general term 'sorption' throughout the paper. Diffusion-controlled physical sorption takes a long time, often several days or weeks. On the basis of the experimental results over $75 \%$ of the copper removal occurs within the first hour of contact with peat. On this basis, we have decided to analyse the data using kinetic models.

The Elovich equation was developed to describe the kinetics of chemisorption of a gas onto solids (Low, 1960), and its differential form is represented in Equation (1). The parameter $\alpha$ represents the rate of chemisorption at zero coverage and the parameter $\beta$ is related to the extent of surface coverage and the activation energy of chemisorption. The application of the Elovich equation is rapidly gaining popularity (Aharoni and Ungarish, 1976; Sparks, 1986). Taylor et al. (1995) successfully used the Elovich equation for the sorption of zinc ions onto soils and Juang and Chen (1997) studied the sorption kinetics of metal ions from sulphate solutions onto solvent impregnated resins. Other applications include work on radioisotopes (Mishra and Singh, 1995; Mishra et al., 1996; Raouf and Daifullah, 1997). 
The Elovich equation is generally expressed as:

$$
d q_{t} / d t=\alpha \exp \left(-\beta q_{t}\right)
$$

where $q_{t}$ is the amount sorbed at time $t$, and $\alpha$ and $\beta$ are constants during any one experiment. The constant $\alpha$ can be regarded as initial rate since $d q_{t} / d t \rightarrow \alpha$ as $q_{t} \rightarrow 0$. Integration of Equation (1) assuming the initial boundary condition $q_{t}=0$ at $t=0$ gives

$$
q_{t}=(1 / \beta) \ln (1+\alpha \beta t)
$$

To simplify the Elovich equation, Chien and Clayton (1980) assumed $\alpha \beta t \gg 1$ and applying the boundary conditions $q_{t}=0$ at $t=0$ and $q_{t}=q_{t}$ at $t=t$ then Equation (2) becomes (Sparks, 1986):

$$
q_{t}=(1 / \beta) \ln (\alpha \beta)+(1 / \beta) \ln (t)
$$

Thus, the constants can be obtained from the slope and intercept of the linearised plots of $q_{t}$ against $\ln (t)$. Equation (3) will be used to test the applicability of the Elovich equation to the kinetics of copper(II) sorption in peat.

For the rate constant of the pseudo-second-order chemical sorption process:

$$
\frac{d q_{t}}{d_{t}}=k\left(q_{e}-q_{t}\right)^{2}
$$

The concentrations are expressed in terms of copper sorbed on sorbent peat, $q$, and for a second-order process, the rate of copper sorption is expressed to the power of the sorbed copper loading difference to the power of two.

where $q_{e}$ is the amount of copper(II) sorbed at equilibrium, (mmol/g); $q_{t}$ is the amount of copper(II) sorbed at time $t,(\mathrm{mmol} / \mathrm{g})$ and $k$ is the equilibrium rate constant of pseudo-second-order sorption, (g/mmol min). Assuming that $q_{t}=0$ at $t=0$, the integrated form of Equation (4) becomes:

$$
\frac{1}{q_{e}-q_{t}}=\frac{1}{q_{e}}+k t
$$

Equation (5) can be rearranged to obtain:

$$
q_{t}=\frac{t}{\frac{1}{k q_{e}^{2}}+\frac{t}{q_{e}}}
$$

Equation (6) can be rearranged to obtain a linear form:

$$
\frac{t}{q_{t}}=\frac{1}{k q_{e}^{2}}+\frac{1}{q_{e}} t
$$


or

$$
\frac{q_{t}}{t}=\frac{k q_{e}^{2}}{1+k q_{e} t}
$$

$h$ can be regarded as initial sorption rate since $t \rightarrow 0$, therefore:

$$
h=k q_{e}^{2}
$$

then Equations (6) and (7) become:

$$
q_{t}=\frac{t}{\frac{1}{h}+\frac{t}{q_{e}}}
$$

and

$$
\frac{t}{q_{t}}=\frac{1}{h}+\frac{1}{q_{e}} t
$$

Thus, a plot of $t / q_{t}$ against $t$ should give a linear relationship with the slope of $1 / q_{e}$ and intercept of $1 / h$ or $1 / k q_{e}^{2}$.

\subsection{EFFECT OF INITIAL CONCENTRATION}

The experimental results of sorption of copper ions on peat at various concentrations are shown in Figure 2. It is apparent from Figure 2 that the amount of copper ions sorbed at equilibrium increases with an increase in initial sorbate concentration. The removal of copper increases by $34.8 \%$ from 0.132 to $0.178 \mathrm{mmol} / \mathrm{dm}^{3}$ (Table I) by increasing the initial copper ions concentration from 0.643 to $1.83 \mathrm{mmol} / \mathrm{dm}^{3}$ at $20^{\circ} \mathrm{C}$ and $\mathrm{pH} 5$. However, the percentage sorption decreases from 82.2 to $39.0 \%$ with an increase in the initial copper ions concentration from 0.643 to $1.83 \mathrm{mmol} / \mathrm{dm}^{3}$.

The corresponding linear plots of the values of $q_{e}, k$ and $h$ against $C_{0}$ were regressed to obtain expressions for these values in terms of the initial copper(II) concentration with high correlation coefficients $(>0.990)$. Therefore it is further considered that $q_{e}, k$ and $h$ can be expressed as a function of $C_{0}$ as follows:

$$
\begin{aligned}
q_{e} & =\frac{C_{0}}{4.55 C_{0}+1.89} \\
k & =\frac{C_{0}}{1.26 C_{0}-0.468} \\
h & =\frac{C_{0}}{32.2 C_{0}-1.18}
\end{aligned}
$$


TABLE I

Parameters for effect of initial concentration

\begin{tabular}{|c|c|c|c|c|c|c|c|c|}
\hline \multirow[b]{2}{*}{$C_{0}$} & \multicolumn{5}{|c|}{ Pseudo-second-order equation } & \multicolumn{3}{|c|}{ Elovich equation } \\
\hline & $r^{2}$ & $q_{e}$ & $R_{e}$ & $k$ & $h$ & $r^{2}$ & $\alpha$ & $\beta$ \\
\hline 0.643 & 0.999 & 0.132 & 82.2 & 1.87 & $3.26 \times 10^{-2}$ & 0.993 & 0.188 & 49.5 \\
\hline 1.33 & 0.998 & 0.171 & 51.4 & 1.07 & $3.13 \times 10^{-2}$ & 0.998 & 0.117 & 33.9 \\
\hline 1.56 & 0.997 & 0.172 & 44.3 & 1.12 & $3.33 \times 10^{-2}$ & 0.999 & 0.150 & 35.6 \\
\hline 1.83 & 0.997 & 0.178 & 39.0 & 0.973 & $3.10 \times 10^{-2}$ & 0.996 & 0.115 & 32.6 \\
\hline
\end{tabular}

$C_{0}: \mathrm{mmol} / \mathrm{dm}^{3} ; q_{e}: \mathrm{mmol} / \mathrm{g} ; k: \mathrm{g} / \mathrm{mmol} \mathrm{min} ; h: \mathrm{mmol} / \mathrm{g} \mathrm{min} ; R_{e}: \%$.

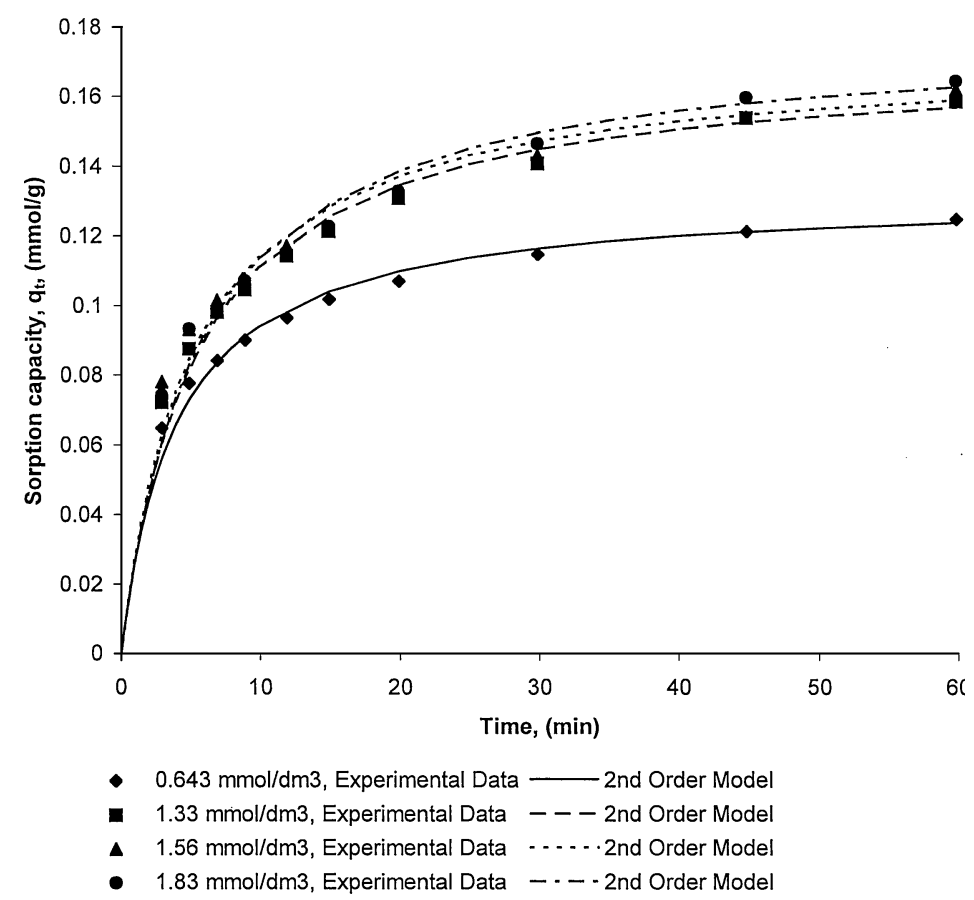

Figure 2. Effect of initial concentration on the sorption of copper ions onto peat.

Substituting the values of $q_{e}$ and $h$ from Equations (10) and (12) into Equation (8), the rate law for a pseudo-second-order reaction and the relationship of $q_{t}, C_{0}$ and $t$ can be represented as:

$$
q_{t}=\frac{C_{0} t}{32.2 C_{0}-1.18+\left(4.55 C_{0}+1.89\right) t}
$$




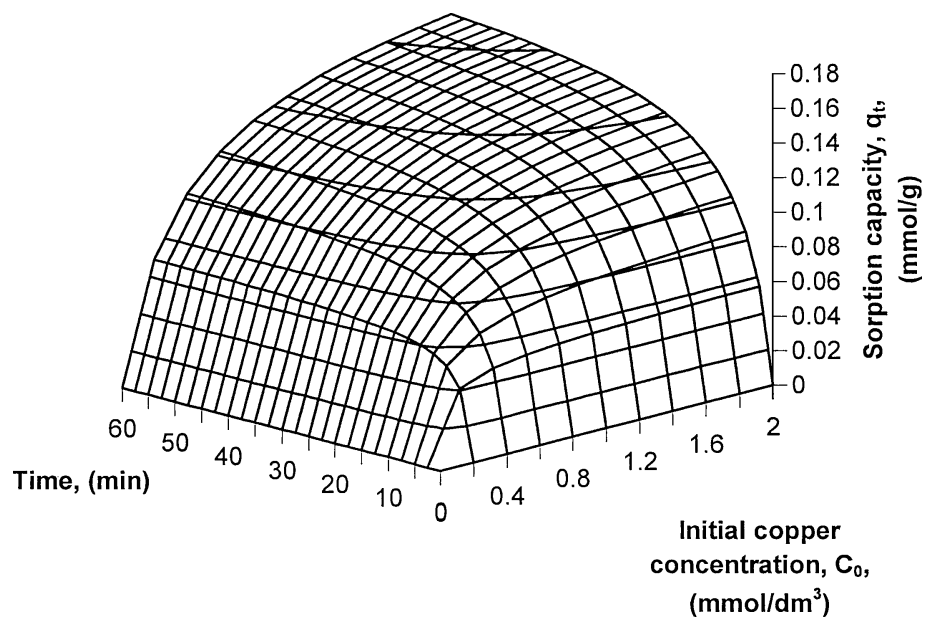

Figure 3. Effect of initial concentration on copper sorption at various reaction times.

Equation (13) represents the generalised predictive model for copper(II) sorbed at any contact time and initial copper(II) concentration within the given range of parameters. It indicates that the copper(II) sorbed at any contact time increases for greater initial copper(II) concentrations. This is obvious, since at for higher $C_{0}$ values, a more efficient utilisation of the sorptive capacity of the sorbent is expected due to greater driving force.

This equation can then be used to derive the amount of copper(II) sorbed at any given copper(II) concentration and the reaction time. The three-dimensional plot of the Equation (13) is shown in Figure 3.

A simple kinetic analysis of sorption on peat has been tested according to the Elovich equation. Figure 4 shows a plot of Equation (3) for the sorption of copper ions with peat. The results demonstrate a highly significant linear relationship between copper(II) sorbed, $q_{t}$, and $\ln (t)$ in these studies with high correlation coefficients $(>0.993)$. The linear correlation coefficients are highly significant. Chien and Clayton (1980) suggest that a simple Elovich equation may be used to describe the kinetics of sorption while a simple first-order kinetic reaction fails. Whereas a plot of Equation (7) for the same data is shown in Figure 5. The agreement between the sets of data reflect the extremely high correlation coefficients obtained and shown in Table I. In other words, the data also show good compliance with the proposed pseudo-second-order equation. Indeed, the regression coefficients for the linear plots were better than 0.997 .

\subsection{EFFECT OF PEAT DOSE}

The effect of varying the peat dose, $m_{s}$, using an initial copper(II) concentration of $1.33 \mathrm{mmol} / \mathrm{dm}^{3}$ at $20^{\circ} \mathrm{C}$ and $\mathrm{pH} 5$ is summarized in Figure 6. Table II shows that 


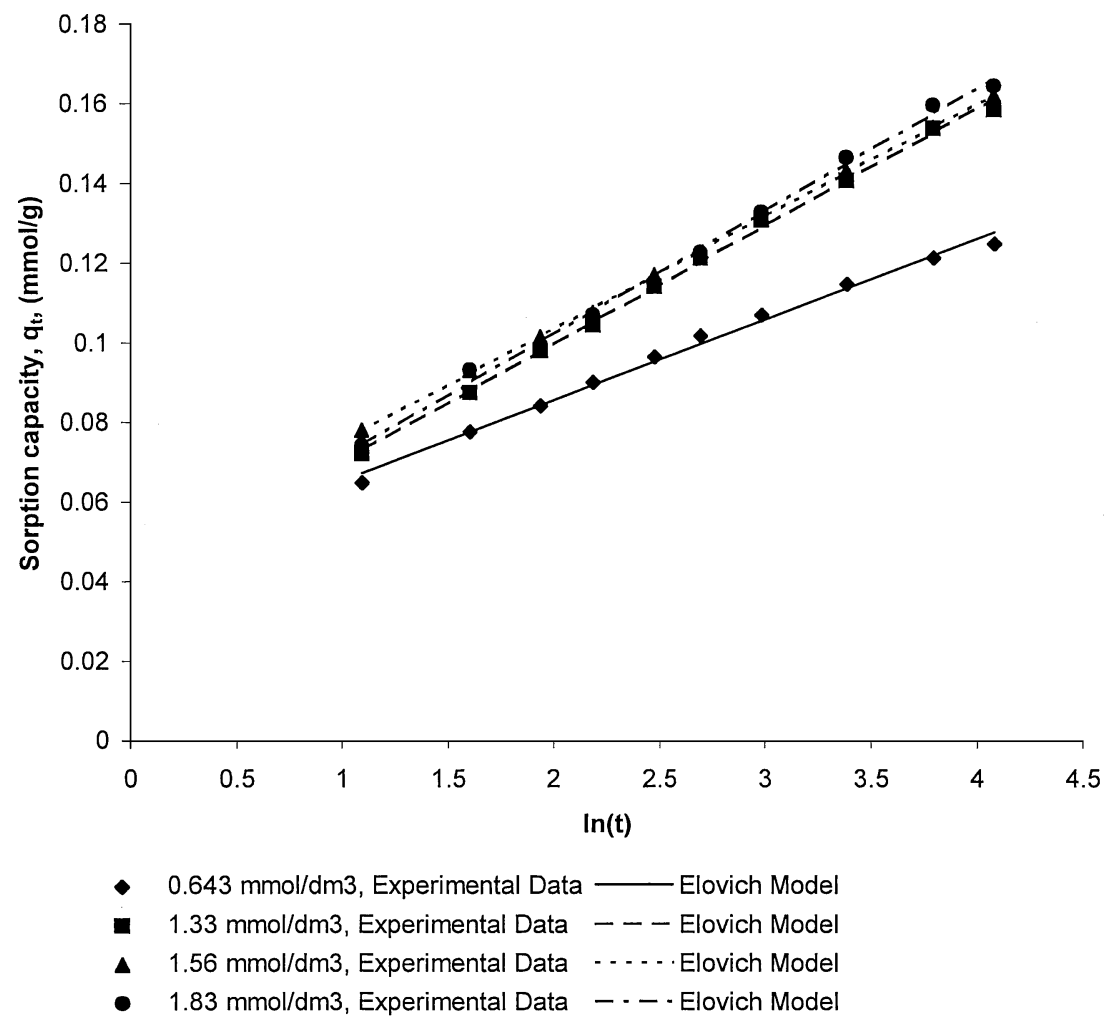

Figure 4. Plot of Elovich equation for sorption of copper ions onto peat at various initial concentrations.

the removal increased from 41.2 to $59.0 \%$ with the peat dose from 3 to $6 \mathrm{~g} / \mathrm{dm}^{3}$. This is to be expected because, for a fixed initial solute concentration, increasing total sorbent doses provides a greater surface area (or sorption sites), although the specific sorption capacity decreased from 0.185 to $0.129 \mathrm{mmol} / \mathrm{g}$ of peat when the doses were increased from 3 to $6 \mathrm{~g} / \mathrm{dm}^{3}$, as shown in Figure 6 .

TABLE II

Parameters for effect of peat dose

\begin{tabular}{|c|c|c|c|c|c|c|c|c|}
\hline \multirow[b]{2}{*}{$m_{s}$} & \multicolumn{5}{|c|}{ Pseudo-second-order equation } & \multicolumn{3}{|c|}{ Elovich equation } \\
\hline & $r^{2}$ & $q_{e}$ & $R_{e}$ & $k$ & $H$ & $r^{2}$ & $\alpha$ & $\beta$ \\
\hline 3 & 0.994 & 0.185 & 41.2 & 0.725 & $2.48 \times 10^{-2}$ & 0.996 & 0.0753 & 29.5 \\
\hline 4 & 0.998 & 0.171 & 51.4 & 1.07 & $3.13 \times 10^{-2}$ & 0.998 & 0.117 & 33.9 \\
\hline 5 & 0.999 & 0.159 & 57.2 & 1.30 & $3.30 \times 10^{-2}$ & 0.997 & 0.147 & 38.4 \\
\hline 6 & 0.998 & 0.129 & 59.0 & 1.55 & $2.57 \times 10^{-2}$ & 0.999 & 0.112 & 47.1 \\
\hline
\end{tabular}

$m_{s}: \mathrm{g} / \mathrm{dm}^{3} ; q_{e}: \mathrm{mmol} / \mathrm{g} ; k: \mathrm{g} / \mathrm{mmol} \mathrm{min} ; h: \mathrm{mmol} / \mathrm{g} \min ; R_{e}: \%$. 


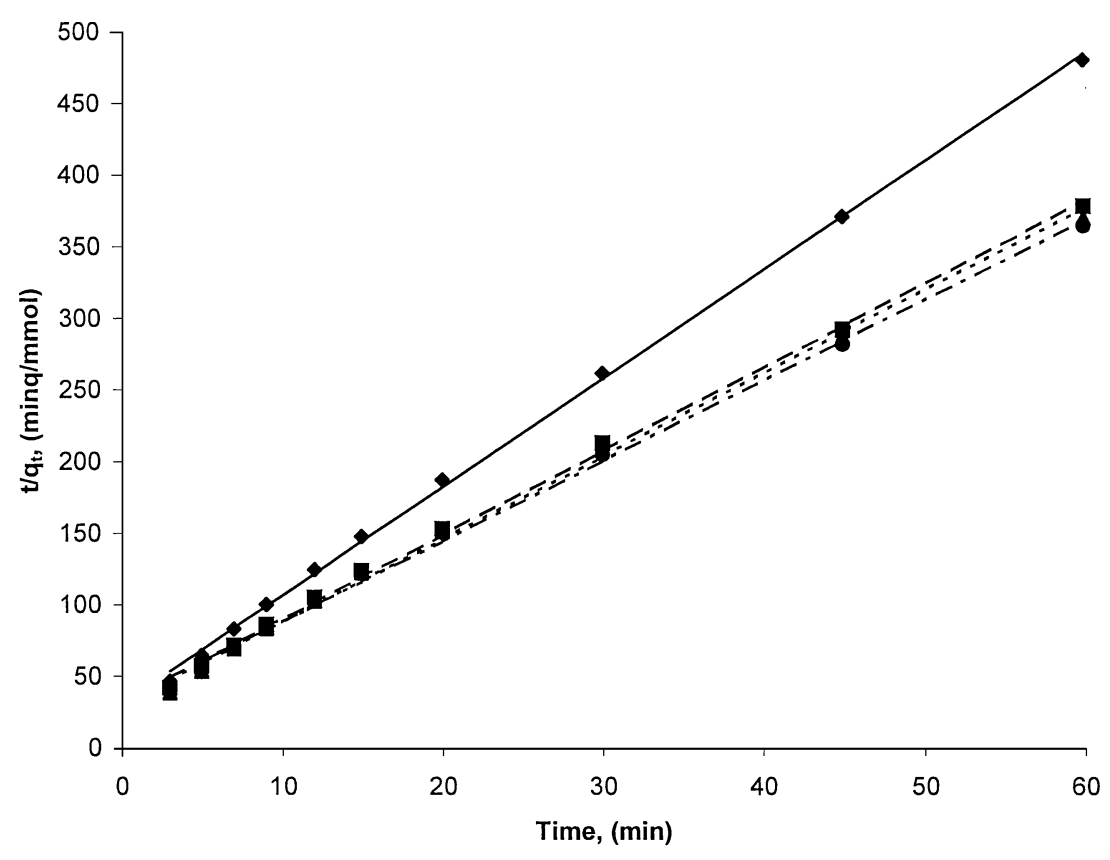

- $0.643 \mathrm{mmol} / \mathrm{dm} 3$, Experimental Data — 2nd Order Model

- $1.33 \mathrm{mmol} / \mathrm{dm} 3$, Experimental Data ---2 nd Order Model

- $1.56 \mathrm{mmol} / \mathrm{dm} 3$, Experimental Data $\cdots \cdot$...2nd Order Model

- $1.83 \mathrm{mmol} / \mathrm{dm} 3$, Experimental Data $-\cdot-\cdot 2$ nd Order Model

Figure 5. Pseudo-second order sorption kinetics of copper ions onto peat at various initial concentrations.

Figure 7 shows the linearised form of the pseudo-second-order model for the sorption of copper(II) onto peat. The correlation coefficients, $r^{2}$, and the pseudosecond-order rate parameters are shown in Table II. The data show a good compliance with the pseudo-second-order equation and the regression coefficients for the linear plots were higher than 0.994 for all the systems in these studies. The results are also shown in Figure 8 as a plot of $q_{t}$ against $\ln (t)$ for sorption of copper(II) for the Elovich equation. The correlation coefficients, $r^{2}$, the Elovich equation parameters $\alpha$ and $\beta$, are shown in Table II. The values of $r^{2}$ for both of the pseudo-second-order and the Elovich equation are all extremely high $(>0.994)$. For the sorption of copper(II) the results can be well represented by both the pseudo-second-order and the Elovich model. The kinetics of chemisorption have been inadequately represented in the literature by the second-order equation and the Elovich Equation (Ungarish and Aharoni, 1981).

On the basis of the excellent fits of both the pseudo-second-order and Elovich correlations, it is possible to propose some potential mechanistic steps. Due to the correlation of the experimental results with the pseudo-second-order model the main sorption mechanism is probably a chemisorption reaction with the predominant 


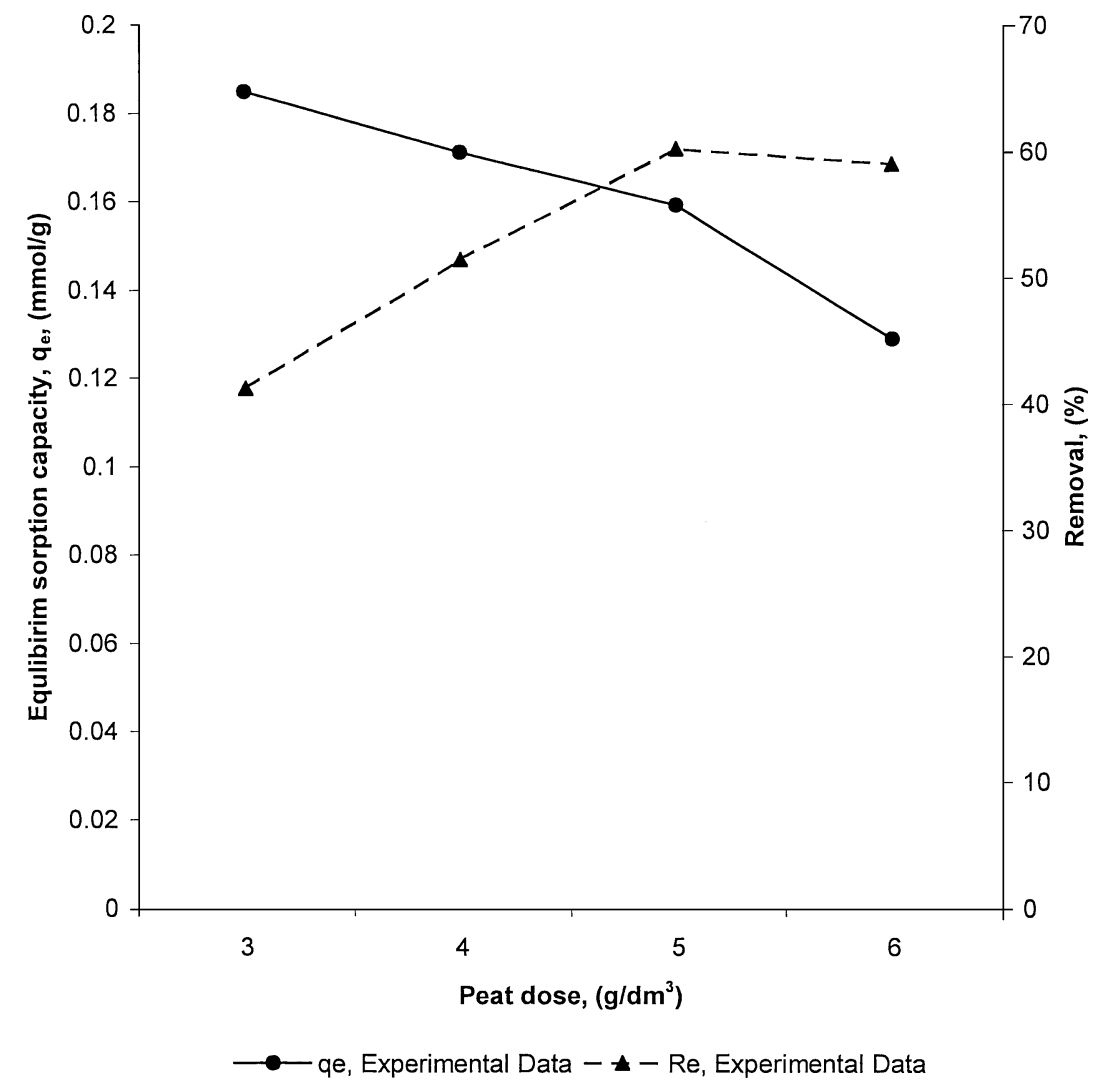

Figure 6. Variation of sorption capacity and percent copper(II) removal against peat dose.

humic acid carboxylic groups:

$$
2 \text { peat }- \text { humic }-\mathrm{COOH}+\mathrm{Cu}^{2+} \rightarrow\left(\text { peat }- \text { humic }-\mathrm{COO}^{-}\right)_{2} \mathrm{Cu}+2 \mathrm{H}^{+}(14 \mathrm{~A})
$$

The Elovich correlation has proved useful for more heterogenous systems and surfaces. Peat is indeed a complex myriad of chemical systems, several of which could participate in metal ion sorption. For example, the weaker carboxylic acid group in fulvic acid:

$$
2 \text { peat }- \text { fulvic }-\mathrm{COOH}+\mathrm{Cu}^{2+} \rightarrow\left(\text { peat }- \text { fulvic }-\mathrm{COO}^{-}\right)_{2} \mathrm{Cu}+2 \mathrm{H}^{+}(14 \mathrm{~B})
$$

Small amounts of amino groups and phenolic hydroxyls could provide lone pairs of electrons for chelating copper ions. Peat is a complex material containing mainly organic residues such as lignin, chelating and cork-like tissues, which are the main constituents of plants. Other compounds present include resins, waxes, proteins and 


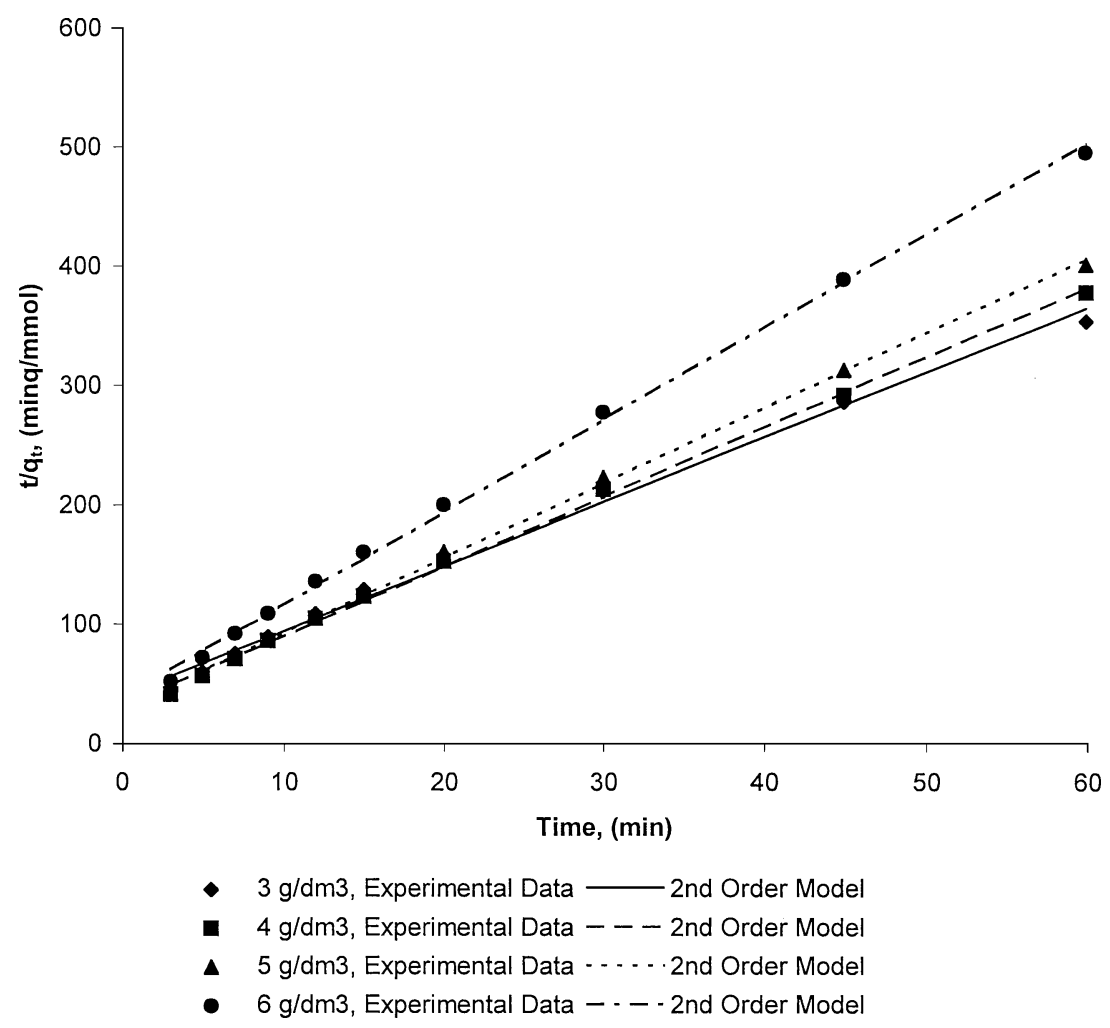

Figure 7. Pseudo-second order sorption kinetics of copper ions onto peat at various peat doses.

dyes. Chemisorption can occur by the polar functional groups of lignin, which include alcohols, aldehydes, ketones, acids, phenolic hydroxyls and ethers as potential chemical bonding agents. Because of this polar character, the adsorption/exchange capacity of peat for metal ions and polar organic molecules is potentially very high. According to Asplund et al. (1972) peat has an extensive surface area $\left(>200 \mathrm{~m}^{2} / \mathrm{g}\right)$ and is extremely porous (95\%). Poots and McKay (1979) measured the specific surface of peat moss using a variety of methods and obtained values of $27 \mathrm{~m}^{2} / \mathrm{g}$ using nitrogen BET, $11.8 \mathrm{~m}^{2} / \mathrm{g}$ using an acid blue dye and $100 \mathrm{~m}^{2} / \mathrm{g}$ using a basic dye. These data demonstrate the presence of negatively charged molecules associated with the polar functional groups of peat as well as the exchange sorption occurring with the hydrogen ions. Peat particles are surface active and have a highcation exchange capacity (Trujillo et al., 1991). Many characteristics influence the sorption/exchange capacity of peat materials including organic matter, particularly humic and fulvic acids (Ravichandran et al., 1988) and interactions and complexation reactions between copper and the peat organic matter (Buffle, 1998).

On the basis of the very complex chemical nature of peat it is not surprising that both kinetic models show a high degree of correlation for the sorption results of copper onto peat. 


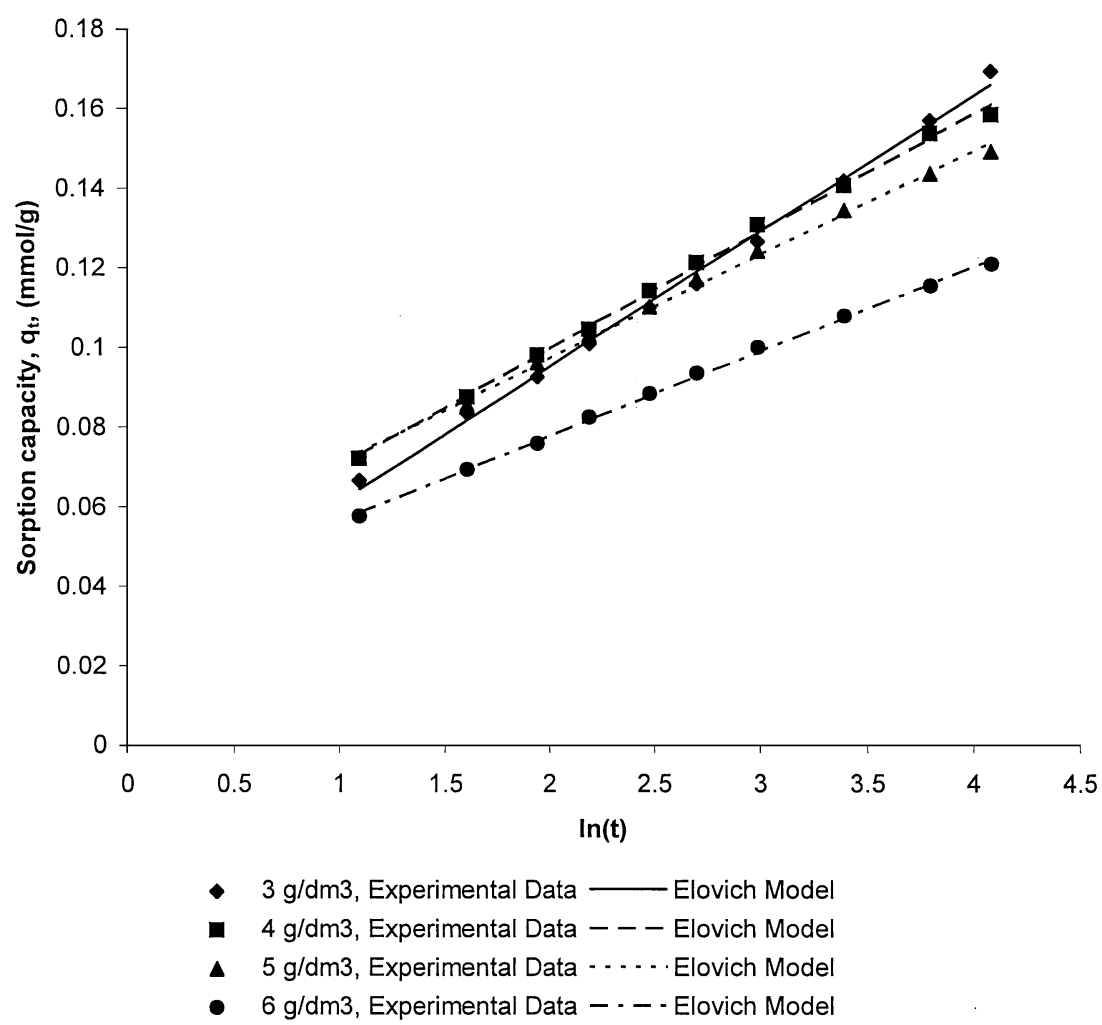

Figure 8. Plot of Elovich equation for sorption of copper ions onto peat at various peat doses.

However, the diversity of peat makes its chemistry more versatile than most other adsorbents (Al-Degs et al., 2000; Boehm, 2002; Strelko and Malik, 2002) containing several functional groups, such as, humic carboxylic, fulvic carboxylic and phenolic are considered to be the three major ones. The roles and exchange potentials of the humic acid group has been discussed and used in the modification of clays for adsorption (Zhou et al., 1994; Vinod and Anirudhan, 2003; Huang and Yang, 1995). Active carbon surfaces usually exhibit surface basicity (MorenoCastilla et al., 1997) due to the reaction type (Abbotsi and Scaroni, 1990).

$$
\mathrm{R}-\mathrm{OH}+\mathrm{H}^{+} \rightarrow \mathrm{R}-\mathrm{OH}_{2}^{+}
$$

For peat, it is expected that its surface chemistry will be dominated by surface acidity dissociation reactions of the type (Strelko and Malik, 2002; Corapcioglu and Huang, 1987).

$$
\begin{aligned}
\mathrm{R}-\mathrm{COOH} & \rightarrow \mathrm{R}_{-} \mathrm{COO}^{-}+\mathrm{H}^{+} \\
\mathrm{R}-\mathrm{OH} & \rightarrow \mathrm{R}_{-} \mathrm{O}^{-}+\mathrm{H}^{+}
\end{aligned}
$$


Many authors (Boyd et al., 1981; da Silva et al., 2002) support the concept that copper reacts with humic acid by chelate ring formation involving adjacent aromatic carboxylate $\mathrm{COOH}$ and phenolic $\mathrm{OH}$ groups, which participate in ion exchange reactions described by Equations (13), (14), (16) and (17) with the release of $\mathrm{H}^{+}$. The mechanism of the peat reaction with metal ions is the subject of extensive discussion. Aho and Tummavouri (1984), Bunzl et al. (1976) and Kadlec and Keolian (1986) developed models based on these ion exchange only type sorption reactions. Other authors (Gangiotti et al., 1984; Gossett et al., 1986; Ringqvist and Oborn, 2002) provided evidence for copper fixing by complexation in addition to ion exchange. The global scheme involved two copper ions interacting with peat as shown:

$$
2 \text { peat }-\mathrm{H}+2 \text { peat }^{-1}+2 \mathrm{Cu}^{2+} \rightarrow 2(\text { peat })_{2} \mathrm{Cu}+2 \mathrm{H}^{+}
$$

in which peat ${ }^{-1}$ is a complexing site.

Structural studies (Averett et al., 1994; Francioso et al., 1996; Spark et al., 1997; Leenheer et al., 1998) using a range of techniques including FT-IR, Raman and NMR, supported the evidence for a metal ion complex involving the carboxylic acid group in the humic and fulvic acids. Furthermore, the authors concluded that there was an innersphere complex of the metal binding fraction and that an outersphere binding complex was also formed.

Therefore, although the pseudo-second-order and the more heterogeneous based Elovich kinetic models both provide excellent model fits for the metal ion concentration versus time decay curve, the myirad of kinetic processes is much more complex in reality.

\subsection{SORPTION ISOTHERMS}

An isotherm is shown in Figure 9 for the sorption of copper(II) onto peat at room temperature. The graph is plotted in the form of copper(II) sorbed per unit mass of peat, $q_{e}$, against the concentration of copper(II) remaining in solution, $C_{e}$, with the Langmuir equation. The correlation coefficient was 1.00. The equilibrium sorption of copper, $X_{m}$, and constant, $a_{L}$, were determined from slope and intercept of the Langmuir equation and found to be $0.199 \mathrm{mmol} / \mathrm{g}$ and $23.4 \mathrm{dm}^{3} / \mathrm{mmol}$, respectively. Figure 9 also shows experimental data with the operating line which is generated with a slope of solution volume/peat mass. The final solution concentration is predicted from the point of intersection of operating line on the sorption isotherm, for the sorption of copper(II). It is therefore an operating line in general form and can be expressed as follows:

$$
q_{m}=\frac{C_{0}-C_{e}}{m_{s}}
$$




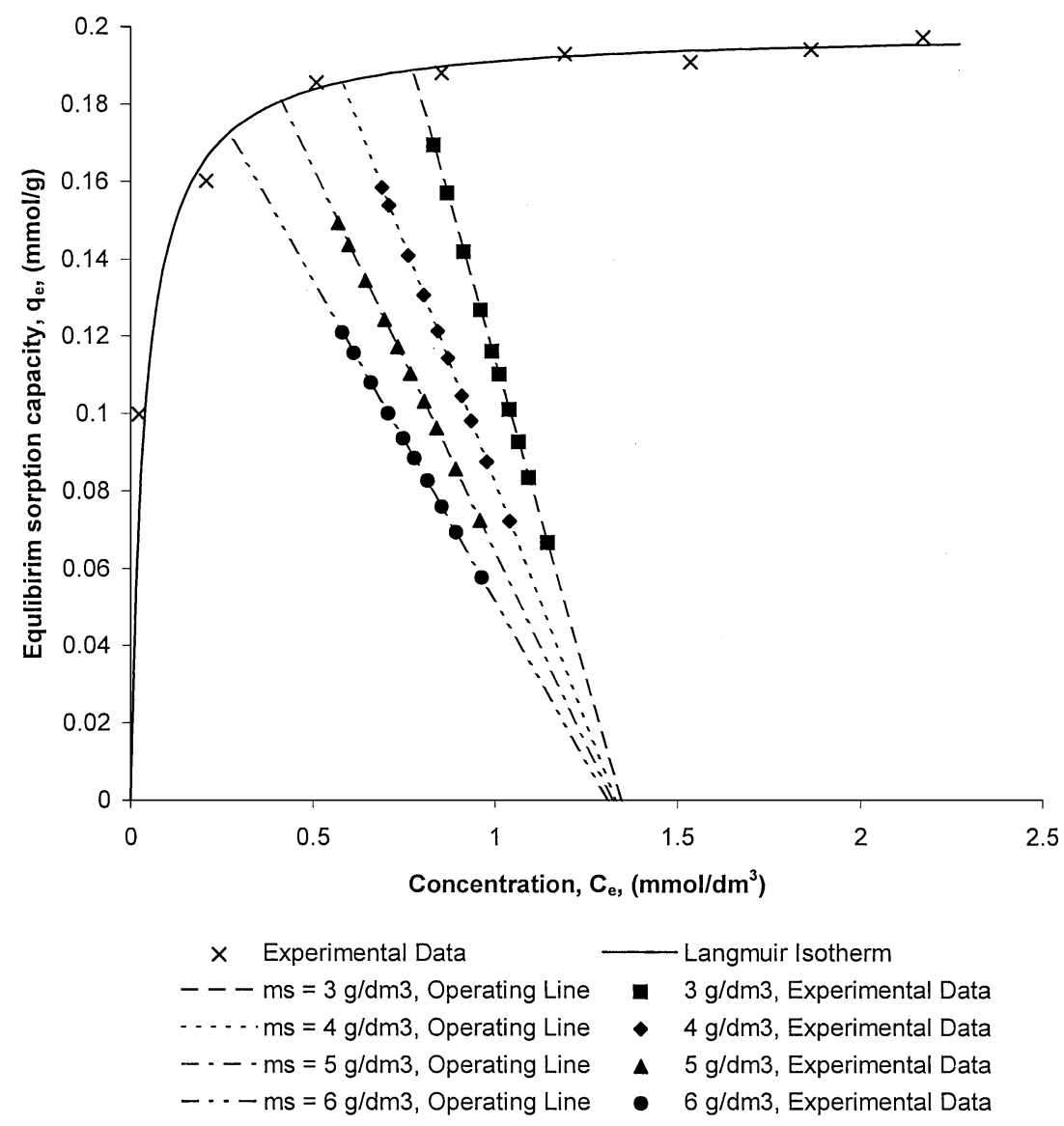

Figure 9. Langmuir isotherm for the sorption of copper of peat mass.

The equilibrium sorption capacity, $q_{m}$, can be obtained from the operating line and the Langmuir equation (Figure 9). The results are in reasonable agreement with the equilibrium sorption capacity, $q_{e}$, which is obtained from the pseudo-second-order model. A comparison is made between the equilibrium sorption capacity evaluated from Langmuir equation and the pseudo-second-order model in Table III, which shows that both equilibrium sorption capacities evaluated are reasonable in all cases except for the low $m_{s}$ value of $3 \mathrm{~g} / \mathrm{dm}^{3}$.

A comparison was also measured at various initial concentrations. The Langmuir isotherms are shown in Figure 10 with the process operating lines. The equilibrium sorption capacity can be obtained from the operating line and the Langmuir equation. A comparison is made between the equilibrium sorption capacity evaluated from Langmuir equation and the pseudo-second-order model in Table IV, which shows both equilibrium sorption capacity evaluated are reasonable in all cases.

The sorption capacities of copper ions from aqueous systems onto various sorbents are compared in Table $\mathrm{V}$ for 16 studies. These are compared with the value 
TABLE III

Comparison of the equilibrium sorption capacity evaluated from Langmuir equation and the pseudo-second-order model

\begin{tabular}{lll}
\hline$m_{s}\left(\mathrm{~g} / \mathrm{dm}^{3}\right)$ & $q_{m}(\mathrm{mmol} / \mathrm{g})$ & $q_{e}(\mathrm{mmol} / \mathrm{g})$ \\
\hline 3 & 0.189 & 0.139 \\
4 & 0.186 & 0.171 \\
5 & 0.181 & 0.199 \\
6 & 0.172 & 0.194 \\
\hline
\end{tabular}

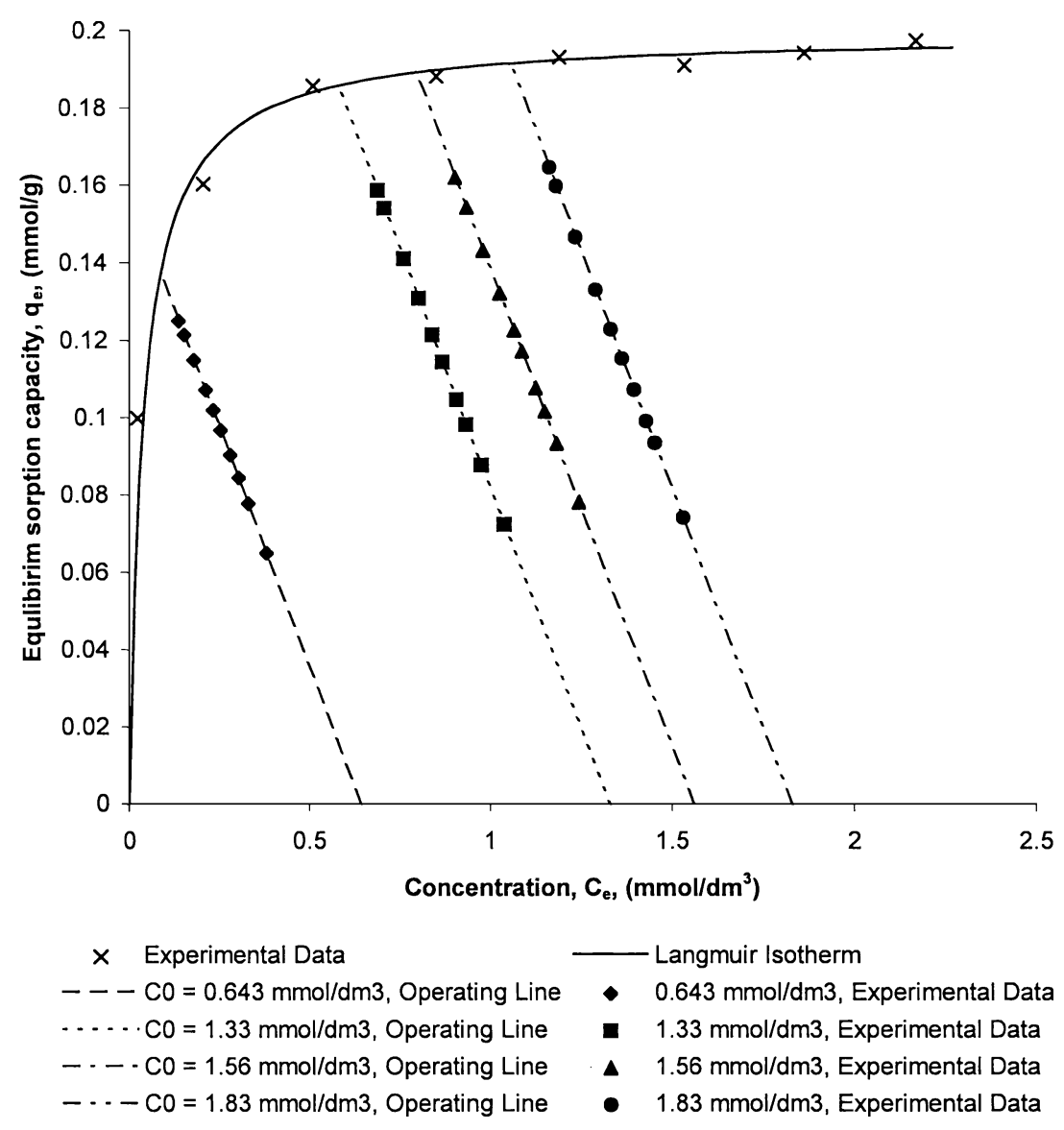

Figure 10. Langmuir isotherm for the sorption of copper of initial copper concentration.

of $12.6 \mathrm{mg} \mathrm{Cu}$ ions/g peat reported in the present study. Over 50 papers have been published in the 1990s on the specific topic of copper sorption, these can summarized. A wide range of capacities for copper ions sorption is observed. In general for sorption capacities of greater than $30 \mathrm{mg} \mathrm{Cu}$ ions/g peat the material has been 
TABLE IV

Comparison of the equilibrium sorption capacity evaluated from Langmuir equation and the pseudo-second-order model

\begin{tabular}{lll}
$C_{0}\left(\mathrm{mmol} / \mathrm{dm}^{3}\right)$ & $q_{m}(\mathrm{mmol} / \mathrm{g})$ & $q_{e}(\mathrm{mmol} / \mathrm{g})$ \\
\hline 0.643 & 0.137 & 0.132 \\
1.33 & 0.186 & 0.171 \\
1.56 & 0.189 & 0.173 \\
1.83 & 0.191 & 0.178 \\
\hline
\end{tabular}

TABLE V

Maximum sorption capacities, $q_{\max }$, of Copper(II) onto various sorbents

\begin{tabular}{|c|c|c|c|c|}
\hline$q_{\max (\mathrm{mg} / \mathrm{g})}$ & Material & Reference & $\mathrm{pH}$ & Temp $\left({ }^{\circ} \mathrm{C}\right)$ \\
\hline 227 & Coconut coir activated & Baes et al., 1996 & 6.0 & 25 \\
\hline 84.0 & Chitosan & Yoshida et al., 1995 & & 25 \\
\hline 65.6 & Peanut hull carbon & Periasamy and Namasiyayam, 1996 & 5.0 & 30 \\
\hline 52.3 & Activated sludge & Sag and Kutsal, 1995 & 4.0 & 45 \\
\hline 19.6 & Eutrophic peat & Chen et al., 1990 & 4.0 & 25 \\
\hline 19.1 & Cottonseed hull carbon & Marshall and Champagne, 1995 & $2-5$ & 25 \\
\hline 16.5 & Acid-treated peat & Bunzl et al., 1976 & & 25 \\
\hline 13.5 & Banana pith carbon & Low et al., 1995 & & \\
\hline 12.6 & Sphagnum peat moss & Present work, 2004 & 5 & 25 \\
\hline 12.1 & Oligotrophic peat & Gossett et al., 1986 & $4-5$ & 25 \\
\hline 9.22 & Activated carbon & Ferro-Garcia et al., 1998 & & 20 \\
\hline 5.90 & Lignite carbon & Allen et al., 1992 & 5 & 20 \\
\hline 3.60 & Granular active carbon & Periasamy and Namasivayam, 1996 & 5 & 25 \\
\hline 3.07 & Coconut husk & Low et al., 1995 & & 20 \\
\hline 2.56 & Lignite & Allen et al., 1997 & & 25 \\
\hline 2.0 & Palmfibre & Low et al., 1993 & & 20 \\
\hline 1.74 & Sawdust & Vaishya and Prasad, 1991 & 7.3 & 25 \\
\hline 1.38 & Fly ash & Panday et al., 1985 & & \\
\hline 0.79 & Aspergillus oryzae & Huang and Huang, 1996 & & \\
\hline
\end{tabular}

acid treated. For the eutrophic sphagnum moss peats, the capacities are mostly in the range of $10-30 \mathrm{mg} / \mathrm{g}$, whereas the oligotrophic peats are mostly $1-15 \mathrm{mg} / \mathrm{g}$. Activated carbons generally show a relatively low-sorption capacity, around $10 \mathrm{mg} / \mathrm{g}$, although a peanut hull based activated carbon has a capacity of $65.6 \mathrm{mg} / \mathrm{g}$. Table V indicates that a number of hulls have been used directly for copper removal including soya bean, cotton seed and coconut husk with wide range of copper sorption capacities of 38.8, 19.1 and 3.1, respectively. Several natural biosorbents having a 
significant cellulose structure have been tested, namely coconut coir, oil palm fibre, banana pith, lignite and sawdust and have the following coppers sorption capacities $227,2.0,13.5,2.6$ and 1.7, respectively. The capacity of $227 \mathrm{mg} \mathrm{Cu} / \mathrm{g}$ using coconut coir is the highest reported literature sorption capacity for copper. A wide variety of microbial biomasses and treated biomasses have been used for copper sorption.

\section{Conclusion}

The ability to peat to sorb copper ion has been studied. The sorption capacity at $20^{\circ} \mathrm{C}$ and the value of $\mathrm{pH} 5$ was $0.199 \mathrm{mmol} / \mathrm{g}$. This capacity of $12.6 \mathrm{mg} \mathrm{Cu}(\mathrm{II}) / \mathrm{g}$ peat compares very well with many capacities reported in the literature. All the materials in Table $\mathrm{V}$ with a higher copper sorption capacity are processed sorbents requiring heat and chemicals. Consequently peat is $5-10 \%$ the cost of these materials. The Langmuir isotherm could be correlated to the experimental data over the studied concentration ranges. For the kinetic sorption studies of copper(II) in an agitated sorber vessel the results can be represented well by both the pseudo-second-order and the Elovich model. Due to the high correlation coefficients obtained by using the Elovich and the pseudo-second-order kinetic model, it is difficult to conclude which sorption mechanisms is actually occurring and is responsible for the ability of peat to sorb copper ions.

Due to the large array of chemical species present in peat moss, which are capable of cation exchange with copper ions, it seems likely that copper ions can exchange with more than one species. The two most likely exchange reactions are copper ions exchanging with hydrogen ions in the humic and fulvic acids present. Consequently, a heterogeneous kinetic model, such as the Elovich equation, seems the most appropriate model for the sorption of copper ions onto sphagnum peat moss.

\section{References}

Abbotsi, G.M.K. and Scaroni, A.W.: 1990, 'Surface Character of Activated Carbons', Carbon 28, 79-86.

Aharoni, C. and Ungarish, M.: 1976, 'Kinetics of Activated Chemisorption. Part 1. The Non-Elovich Part of the Isotherm', J. Chem. Soc.-Faraday Trans. 72, 400-408.

Aho, M. and Tummavuori, J.: 1984, 'On the Ion-Exchange Properties of Peat-IV. The Effect of Experimental Conditions on Ion Exchange Properties of Sphagnum Peat', Suo 35, 47-53.

Al-Degs, Y., Khraisheh, M.A.M., Allen, S.J. and Ahmad, M.N.: 2000, 'Effect of Carbon Surface Chemistry on the Removal of Reactive Dyes from Textile Effluent', Water Res. 34, 927-935.

Allen, S.J., Brown, P., McKay, G. and Flynn, O.: 1992, 'An Evaluation of Single Resistance Transfer Models in the Sorption of Metal Ions by Peat', J. Chem. Technol. Biotechnol. 54, 271-276.

Allen, S.J., Whitten, L.J., Murray, M. and Duggan, O.: 1997, 'The Adsorption of Pollutants by Peat, Lignite and Activated Chars', J. Chem. Technol. Biotechnol. 68, 442-452. 
Asplund, D., Ekman, E. and Thun, R.: 1972, 'Counter-Current Peat Filtration of Waste Water', Proc. 4th Int. Peat Congr. 5, 358-371.

Averett, R.C., Leenheer, J.A., McKnight, D.M. and Thorn, K.A.: 1994, 'Humic Substances in the Suwanne River, Georgia: Interactions, Properties and Proposed Structure', U.S. Government Printing Office, Washington, DC, pp. 224-233.

Baes, A.U., Umali, S.J.P. and Mercado, R.L.: 1996, 'Ion Exchange and Adsorption of Some Heavy Metals in a Modified Coconut Coir Cation Exchanger', Water Sci. Technol. 34, 193-200.

Boehm, H.P.: 2002, 'Surface Oxides on Carbon and Their Analysis: A Critical Assessment', Carbon 40, 145-149.

Boyd, S.A., Sommers, L.E. and Nelson, D.W.: 1981, 'Copper(II) and Iron(III) Complexation by the Carboxylate Group of Humic Acid', J. Soil Sci. Soc. Am. 45, 1241-1242.

Buffle, J.: 1998, 'Complexation Reactions in Aquatic Systems: An Analytical Approach', Ellis Horwood, Chichester, England.

Bunzl, K., Schmidt, W. and Sansoni, B.: 1976, 'Kinetics of Ion Exchange in Soil Organic Matter. IV.: Adsorption and Desorption of $\mathrm{Pb}^{2+}, \mathrm{Cu}^{2+}, \mathrm{Cd}^{2+}, \mathrm{Zn}^{2+}$ and $\mathrm{Ca}^{2+}$ by Peat', J. Soil Sci. Am. 27, $32-41$.

Chen, X.-H., Gossett, T. and Thevenot, D.R.: 1990, 'Batch Copper Ion Binding and Exchange Properties of Peat', Water Res. 24, 1463-1471.

Chien, S.H. and Clayton, W.R.: 1980, 'Application of Elovich Equation to the Kinetics of Phosphate Release and Sorption in Soils', J. Soil Sci. Soc. Am. 44, 265-268.

Coleman, N.T., McClung, A.C. and Moore, D.P.: 1956, 'Formation Constants for Cu(II)-Peat Complexes', Science 123, 330-331.

Corapcioglu, M.O. and Huang, C.P.: 1987, 'The Adsorption of Heavy Metals onto Hydrous Activated Carbon', Water Res. 21, 1031-1044.

Da Silva, W.T.L., Thobie-Gauttier, C. and Rezende, M.O.O.: 2002, 'Electrochemical Behaviour of $\mathrm{Cu}(\mathrm{II})$ on Carbon Paste Electrode Modified by Humic Acid, Cyclic Voltammetry Study', Electroanalysis 14(1), 71-77.

Ferro-García, M.A., Rivera-Utrilla, J., Rodríguez-Gordillo, J. and Bautista-Toledo, I.: 1998, 'Adsorption of Zinc, Cadmium and Copper on Activated Carbons Obtained from Agricultural byProducts', Carbon 26, 363-373.

Findon, A., McKay, G. and Blair, H.S.: 1993, 'Transport Studies for the Sorption of Copper Ions by Chitosan', J. Env. Sci. Health Part A-Env. Sci. Eng. Toxic Hazard. Subs. Control 28, 173-185.

Francioso, O., Sanchez-Cortes, S., Tugnoli, V., Ciavatta, C., Sitti, L. and Gessa, C.: 1996, Infrared, Raman and Nuclear Magnetic Resonance $\left({ }^{1} \mathrm{H},{ }^{13} \mathrm{C}\right.$ and $\left.{ }^{31} \mathrm{P}\right)$ Spectroscopy in the Study of Fractions of Peat Humic Acids', Appl Spectrosc. 50, 1165-1174.

Furusawa, T. and Smith, J.M.: 1973, 'Fluid-Particle and Intraparticle Mass Transport Rates in Slurries', Ind. Eng. Chem. Fundam. 12, 197-203.

Furusawa, T. and Smith, J.M.: 1974, 'Intraparticle Mass Transport in Slurries by Dynamic Adsorption Studies', AIChE J. 20, 88-93.

Gangiotti, L., Chen, X.-H. and Thevenot, D.R.: 1984, 'Research Report: pH Dependence of Copper Fixation on Peat', Universite Paris-Val de Marne, Creteil, France.

Gosset, T., Trancart, J.L. and Thevenot, D.R.: 1986, 'Batch Metal Removal by Peat Kinetics and Thermodynamics', Water Res. 20, 21-26.

Ho, Y.S., Huang, C.T. and Huang, H.W.: 2002, 'Equilibrium Sorption Isotherm for Metal Ions on Tree Fern', Proc. Biochem. 37, 1421-1430.

Ho, Y.S. and McKay, G.: 2000, 'Batch Sorber Design Using Equilibrium and Contact Time Data for the Removal of Lead', Water, Air, Soil Pollut. 124, 141-153.

Ho, Y.S., Wase, D.A.J. and Forster, C.F.: 1994, 'The Adsorption of Divalent Copper Ions from Aqueous Solution by Sphagnum Moss Peat', Trans. Inst. Chem. Eng. part B: Proc. Safety Env. Prot. 17, 185-194. 
Ho, Y.S., Wase, D.A.J. and Forster, C.F.: 1995, 'Batch Nickel Removal from Aqueous Solution by Sphagnum Moss Peat', Water Res. 29, 1327-1332.

Huang, C. and Huang, C.P.: 1996, 'Application of Aspergillus Oryzae and Rhizopus Oryzae for Cu(II) Removal', Water Res. 30(9), 1985-1990.

Huang, C. and Yang, Y.: 1995, 'Adsorption Characteristics of Cu(II) on Humus-Kaolin Complexes', Water Res. 29, 2455-2460.

Juang R.S. and Chen, M.L.: 1997, 'Application of the Elovich Equation to the Kinetics of Metal Sorption with Solvent Impregnated Resins', Ind. Eng. Chem. Res. 36, 813-820.

Kadirvelu, K. and Namasivayam, C.: 2003, 'Activated Carbon from Coconut Coirpith as Metal Adsorbent: Adsorption of Cd(II) from Aqueous Solution', Ad. Environ. Res. 7, 471-478.

Kadlec, R.H. and Keoleian, G.A.: 1986, Peat and Water, Fuchsman, C.H. (ed.), Elsevier Applied Science Publishers, London, pp. 61-93.

Leenheer, J.A., Brown, G.K., McCarthym P. and Cabaniss, S.E.: 1998, 'Models of Metal Binding Structures in Fulvic Acid from the Suwannee River Georgia', Env. Sci. Technol. 32, 24102416.

Low, M.J.D.: 1960, 'Kinetics of Chemisorption of Gases on Solids', Chem. Rev. 60, 267-312.

Low, K.S., Lee, C.K. and Lee, K.P.: 1993, 'Sorption of Copper by Dye-Treated Oil-Palm Fibers', Biores. Technol. 44, 109-112.

Low, K.S., Lee, C.K., Lee, A.C.: 1995, 'Removal of Metals from Electroplating Wastes Using Banana Pith', Biores. Technol. 51 (2, 3), 227-231.

Low, K.S., Lee, C.K., Wong, S.L.: 1995, 'Effect of Dye Modification on the Sorption of Copper by Coconut Husk', Environ. Technol. 16(9), 877-883.

Luckey, T.D. and Venugopal, B.: 1977, 'Metal Toxicity in Mammals, Physiologic and Chemical Basis for Metal Toxicity', Vol. 1, Plenum, New York and London.

Marshall, W.E. and Champagne, E.T.: 1995, 'Agricultural By-Products as Adsorbents for Metal-Ions in Laboratory Prepared Solutions and in Manufacturing Waste-Water', J. Env. Sc. Health Part A-Env. Sci. Eng. Toxic Hazard. Subst. 30, 241-261.

Marshall, W.E., Champagne, E.T. and Evans, W.J.: 1993, 'Use of Rice Milling By-Products (Hulls and Bran) to Remove Metal-Ions from Aqueous-Solution', J. Env. Sci. Health Part A-Env. Sci. Eng. Toxic Hazard. Subst. Control 28(9), 1977-1992.

McKay, G., Otterburn, M.S. and Sweeney, A.G.: 1978, 'The Removal of Colour from Effluent Using Various Adsorbents: Some Preliminary Economic Considerations', J. Soc. Dyers Colourists 94, 357-360.

Mishra, S.P. and Singh, V.K.: 1995, 'Efficient Removal of Cadmium Ions from Aqueous Solutions by Hydrous Ceric Oxide-A Radiotracer Study', Radiochimica Acta 68, 251-256.

Mishra, S.P., Singh, V.K. and Tiwari, D.: 1996, 'Radiotracer Technique in Adsorption Studies: Part XIV. Efficient Removal of Mercury from Aqueous Solutions by Hydrous Zirconium Oxide', Appl. Radiat. Isot. 47, 15-21.

Moreno-Castilla, C., Carrasco-Marin, F. and Mueden, A.: 1997, 'The Creation of Acid Carbon Surfaces by Treatment with $\left(\mathrm{NH}_{4}\right)(2) \mathrm{S}_{2} \mathrm{O}_{8}$ ', Carbon 35, 1619-1626.

Namasivayam, C. and Kadirvelu, K.: 1997, 'Agricultural Solid Wastes for the Removal of Heavy Metals: Adsorption of Cu(II) by Coirpith Carbon', Chemosphere 34, 377-399.

Ngah, W.S.W., Endud, C.S. and Mayanar, R.: 2002, 'Removal of Copper(II) Ions from Aqueous Solution onto Chitosan and Cross-Linked Chitosan Beads', React. Funct. Polym. 50, 181-190.

Ong, H.L. and Swanson, V.E.: 1966, 'Adsorption of Copper by Peat, Lignite, and Bituminous Coal', Econ. Geol. 61, 1214-1231.

Panday, K.K., Prasad, G. and Singh, V.N.: 1985, 'Copper(II) Removal from Aqueous Solution by Fly Ash', Water Res. 19, 869-873.

Periasamy, K. and Namasivayam, C.: 1996, 'Removal of Copper(II) by Adsorption onto Peanut Hull Carbon from Water and Copper Plating Industry Wastewater', Chemosphere 32, 769-789. 
Poots, V.J.P. and McKay, G.: 1979, 'Specific Surfaces of Wood and Peat', J. Appl. Polym. Sci. 11171129.

Raouf, M.W.A. and Daifullah, A.A.M.: 1997, 'Potential Use of Bone Charcoal in the Removal of Antimony and Europium Radioisotopes from Radioactive Wastes', Ads. Sci. Technol. 15(8), 559569.

Ravichandran, M., Aiken, G.R., Reddy, M.M. and Ryan, J.N.: 1988, 'Enhanced Dissolution of Cinnabar (Mercuric Sulphide) by Dissolved Organic Matter Isolated from the Florida Everglades', Env. Sci. Technol. 32(21), 3305-3311.

Ringqvist, L. and Oborn, I.: 2002, 'Copper and Zinc Adsorption onto Poorly Humidified Sphagnum and Carex Peat', Water Res. 36(9) 2233-2242.

Sag, Y. and Kutsal, T.: 1995, 'Biosorption of Heavy Metals by Zoogloea Ramigera: Use of Adsorption Isotherms and a Comparison of Biosorption Characteristics', Chem. Eng. J. Biochem. Eng. J. 60(13), 181-188.

Sharma, D.C. and Forster, C.F.: 1993, 'Removal of Hexavalent Chromium Using Sphagnum Moss Peat', Water Res. 27(7), 1201-1208.

Spark, K.M., Wells, J.D. and Johnson, B.B.: 1997, 'The Interaction of a Humic Acid with Heavy Metals', Aust. J. Soil Res. 35, 89-101.

Sparks, D.L.: 1986, 'Kinetics of Reaction in Pure and Mixed Systems', in Sparks, D.L. (ed.), Soil Physical Chemistry, CRC Press, Boca Raton, Florida, pp. 83-145.

Strelko, V. and Malik, D.J. Jr.: 2002, 'Characterization and Metal Sorptive Properties of Oxidized Active Carbon', J. Coll. Interf. Sci. 250, 213-220.

Taylor, R.W., Hassan, K., Mehadi, A.A. and Shuford, J.W.: 1995, 'Kinetics of Zinc Sorption by Soils', Commun. Soil Sci. Plant Anal. 26, 1761-1771.

Trujillo, E.M., Jeffers, T.H., Ferguson, C. and Stevenson, H.Q.: 1991, 'Mathematically Modeling the Removal of Heavy Metals from a Wastewater Using Immobilized Biomass', Env. Sci. Technol. 25, 1559-1564.

Ungarish, M. and Aharoni, C.: 1981, 'Kinetics of Chemisorption: Deducing Kinetic Laws from Experimental Data', J. Chem. Soc.-Faraday Trans. 77, 975-985.

Vaishya, R.C. and Prasad, S.C.: 1991, 'Adsorption of Copper(II) on Sawdust', Indian J. Environ. Prot. 11, 284-289.

Vinod, V.P. and Anirudhan, T.S.: 2003, 'Adsorption Behaviour of Basic Dyes on the Humic Acid Immobilized Pillared Clay', Water, Air, Soil Pollut. 150, 193-217.

Viraraghavan, T. and Dronamraju, M.M.: 1993, 'Removal of Copper, Nickel and Zinc from Wastewater by Adsorption Using Peat', J. Environ. Sci. Health Part A-Environ. Sci. Toxic. Hazard Subst. Control. A27, 1261-1276.

Yoshida, H., Kishimoto, N. and Kataoka, T.: 1995, 'Adsorption of Glutamic-Acid on Polyaminated Highly Porous Chitosan-Equilibria', Ind. Eng. Chem. Res. 34(1), 347-355.

Zhou, J.L., Rowland, S., Mantouva, F.C. and Braven, J.: 1994, 'The Formation of Humic Coatings on Mineral Particles Under Simulated Estuarine Conditions-A Mechanistic Study', Water Res. 25, 571-579. 